\title{
Prioritizing Access of Renewable Energy to the Grid in China: Regulatory Mechanisms and Challenges for Implementation
}

\author{
Hao ZHANG \\ Assistant Professor, Faculty of Law, The Chinese University of Hong Kong \\ haozhang@cuhk.edu.hk
}

\begin{abstract}
Following decades of fast growth in China's power sector, underpinned by considerable investment in coal-fired generation, in recent years there has been a decisive move towards increasing energy supply that is climate and environmentally friendly. In order to meet this policy agenda, a number of regulatory mechanisms have been established to support and further the implementation of China's Renewable Energy Law. A key feature of these regulatory developments has been increased regulation and enforcement of the obligation to ensure priority access of renewable energy to the power grid and full purchase of renewable energy generation. In practice, however, utilising electricity generation from renewable sources has been significantly curtailed. This article analyses whether the law and policy frameworks provide sufficient support and protection to ensure priority access of renewable energy in China. By considering relevant Chinese law cases, this article also provides insights into the judicial and regulatory practices in relation to curtailment disputes, particularly the limited transparency of the mediation process and the challenges faced by renewable energy generators in bringing cases to court.
\end{abstract}

\section{Keywords}

China - climate change - curtailment - grid access disputes - guaranteed full purchase - priority grid access - regulatory mechanisms - renewable energy generation - renewable energy law and policy 
For many decades, the fast growth in China's power sector has been characterised by sizeable investment in coal-fired generation, and escalating energy sector greenhouse gas emissions (GGEs). ${ }^{1}$ In response to mounting pressure to mitigate GGEs and reduce air pollution caused by excessive coal-fired generation, the role of renewable energy in China's overall energy consumption has become increasingly important. ${ }^{2}$ To meet this growing demand, China has been decisively moving towards energy supply that is climate- and environment- friendly. ${ }^{3}$ This is evident in China's energy policy focus on developing 'a clean, low carbon, safe and efficient energy system,' ${ }^{4}$ and on promoting a transition aimed at boosting renewable energy production and advancing energy efficiency in major industrial sectors. ${ }^{5}$ China's Renewable Energy Law,

* This research has benefited from the Chinese University of Hong Kong Direct Grant for Research (4059043). The author is grateful to Anatole BOUTE for comments on an earlier version of this paper and the two anonymous referees for insightful comments to further improve the paper. The editorial assistance from one of this Journal's associate editors, Dr Rowena CANTLEY-SMITH is especially acknowledged. The usual disclaimer applies.

1 In 2018, the three largest contributors to increases in global greenhouse gas emissions were China, India, and the UsA. See further, Climate Action Tracker, 'Climate crisis demands more government action as emissions rise' (New Climate Institute and Climate Analytics, June 2019 Update) <https://climateactiontracker.org/documents/537/CAT_2019-06-19_SB50_ CAT_Update.pdf $>$; World Resources Institute, WRI China $<$ wri.org.cn/en $>$ and Chinese website $<$ wri.org.cn/ $>$.

2 State Council, 'The 13th Five-year Plan for Economic and Social Development of the People's Republic of China' (中华人名共和国国民经济和社会发展第十三个五年规划纲要) (2016) Ch 30 <www.gov.cn/xinwen/2016-03/17/content_5054992.htm>; English version <en .ndrc.gov.cn/newsrelease/201612/Po20161207645765233498.pdf>.

3 State Council, 'Notice of the State Council on Issuing the 12th Five-Year Plan for Energy Development' (国务院关于印发能源发展 “十二五” 规划的通知) (2013) No $2<\mathrm{http}: / /$ www.gov.cn/zwgk/2013-01/23/content_2318554.htm>. It is important to note that the renewable energy generation/generators in this article refer to upstream electricity generation. While downstream distributed renewable energy generation is also encouraged and supported by the relevant legal framework, the access issues are governed by a separate set of rules. See eg, National Development and Reform Commission (NDRC), 'Interim Measures for Managing Distributed Electricity Generation' (分布式发电管理暂行办法) (2013) No 1381 <http://www.ndrc.gov.cn/zcfb/zcfbtz/201308/Wo20130813592731850506.pdf>.

4 Energy Research Institute of Academy of Macroeconomic Research/NDRC and China National Renewable Energy Centre, 'China Renewable Energy Outlook 2018: Executive Summary' (2018) 1 <boostre.cnrec.org.cn/wp-content/uploads/2018/12/CNREC_China -Renewable-Energy-Outlook-2018_Executive-Summary_ENG.pdf>.

5 Sara SCHUMAN and Alvin LIN, 'China's Renewable Energy Law and its Impact on Renewable Power in China: Progress, Challenges and Recommendations for Improving Implementation' (2012) 51 Energy Policy 89; Lynn PRICE, Xue-Jun WANG and Jiang YUN, 'The Challenge 
promulgated in 2005 and amended further in 2009 (REL 2005/2009), ${ }^{6}$ is central to meeting this energy policy agenda. ${ }^{7}$ Key purposes of the REL 2005/2009 include 'promoting development and utilization of renewable energy' and environmental protection. ${ }^{8}$ In meeting its stated purposes, the REL 2005/2009 sets down several mechanisms, including 'a national long- and medium-term total target for the development and utilization of renewable energies, ${ }^{9}$ prioritized grid access for renewable energy generators, ${ }^{10}$ a guaranteed full purchase of renewable energy by grid enterprises, ${ }^{11}$ and a national feed-in tariff (FiT) system. ${ }^{12}$ Additional policies and regulations have been promulgated and enforced to aid the implementation of the REL 2005/2009. A number of these focus on ensuring priority access of renewable energy to the national power grid..$^{13}$ At a policy level, considerable advancements are also underway to 'boost power system flexibility and support clean energy investment.'14 For example, the power system reforms articulated by the State Council in 2015 are being carried out to transform the electricity sector into a more flexible and efficient one that accommodates increased renewable energy consumption. ${ }^{15}$ The 2015 reforms, with the policy objective to deregulate China's power sector

of Reducing Energy Consumption of the Top-100o Largest Industrial Enterprises in China' (2010) 38 Energy Policy 6485 .

6 Renewable Energy Law of the People's Republic of China (中华人民共可再生能源法) (Adopted at the 14th Meeting of the Standing Committee of the Tenth National People's Congress on February 28, 2005; Amended according to the Decision of the 12th Meeting of the Standing Committee of the 11th National People's Congress of the People's Republic of China on December 26, 2009) (REL 2005/2009) <http://www.cnrec.info/zcfg /gnzc/zhzc/2012-05-18-741.html>;Englishversion<english.mofcom.gov.cn/article/policyre lease/Businessregulations/201312/2013120043216o.shtml >.

$7 \quad$ REL 2005/2009, Ibid.

8 REL 2005/2009 (n 6) art 1.

9 REL 2005/2009 (n 6) art 7.

$10 \quad$ REL 2005/2009 (n 6) art 14.

11 REL 2005/2009 (n 6) art 14.

12 REL 2005/2009 (n 6) art 19.

13 A list of additional regulatory documents is provided in the Table at the end of this article.

14 International Renewable Energy Agency (IRena), International Energy Agency and Renewable Energy Policy Network for the 21st Century, Renewable Energy Policies in a Time of Transition (IEA/OECD/REN21, 2018) <www.irena.org/-media/Files/IRENA/Agency /Publication/2018/Apr/IRENA_IEA_REN21_Policies_2018.pdf $>$. See also eg, International Energy Agency(IEA),ChinaPowerSystem Transformation:Assessing theBenefitofOptimised Operations and Advanced Flexibility Options (IEA/OECD, 2019) <www-oecd-ilibrary-org .ezproxy.lib.uts.edu.au/energy/china-power-system-transformation_22655cco-en>.

15 State Council, 'Opinions of the State Council on Further Reforming the Electric Power System' (中共中央国务院关于进一步深化电力体制改革的若干意见) (2015) No 9 <http://tgs.ndrc.gov.cn/zywj/201601/t20160129_773852.html>. 
for higher economic efficiency, has cautiously liberalized electricity pricing to facilitate direct trading between power generators and manufacturers. ${ }^{16}$ It is clear therefore, that efforts are clearly being made to establish the 'right framework conditions' to effect necessary changes to the national power system, with renewable energy policies and laws being promulgated to facilitate 'a much stronger integration between the demand and supply sides' and to allow for 'a more rapid uptake' of renewable energy generation resources. ${ }^{17}$

Even so, a key feature of power systems is that energy generators, from renewable and other fuel sources, not only have access to the grid, but also expect that the electricity they produce will be dispatched by grid operators. ${ }^{18}$ When this does not occur, which can happen for a variety of reasons, renewable energy supply from particular generators is curtailed, and investors are struck with financial losses. ${ }^{19}$ Given the importance of renewable energy generation and grid access, such matters are often safeguarded by polices and laws in many countries, including China. ${ }^{20}$ Notably, Article 14 of China's REL $2005 / 2009$ requires that renewable energy generators are to be given mandatory access to the grid, and further, that electricity generated from renewable energy is to be fully purchased by the grid enterprises. ${ }^{21}$ Nonetheless, fulfilling these requirements has not been as successful as intended. ${ }^{22}$ On the contrary, in 2016 for example, the curtailment of wind power (meaning that electricity was generated but not dispatched) across China's electricity system reached 49,700 GWh, which accounted for 17.2 per cent of the total wind power

16 Ibid.

17 IEA (n 14) 6.

18 Ye QI, Jiaqi LU and Mengye ZHU, 'Wind Curtailment in China and Lessons from the United States' (Brookings-Tsinghua Center for Public Policy, 2018) <www.brookings.edu /wp-content/uploads/2018/o3/wind-curtailment-in-china-and-lessons-from-the-united -states.pdf>.

19 Henrik KLINGE JACOBSEN and Sascha THORSTEN SCHRÖDER, 'Curtailment of Renewable Generation: Economic Optimality and Incentives' (2012) 49 Energy Policy 663.

20 Xiaodong WANG, 'Legal and Policy Frameworks for Renewable Energy to Mitigate Climate Change' (2007) 7 Sustainable Development Law \& Policy 17. For more recent discussion see eg, Irena (n 29); IEA/Irena Global Renewable Energy Policies and Measures Database <www.iea.org/policiesandmeasures/renewableenergy/>.

21 REL 2005/2009 (n 6) article 14.

22 Canbing LI, Haiqing SHI, Yijia CAO, Jianhui WANG, Yonghong KUANG, Yi TAN, Jing WEI, 'Comprehensive Review of Renewable Energy Curtailment and Avoidance: A Specific Example in China' (2015) 41 Renewable and Sustainable Energy Reviews 1067; Fredrich KAHRL, Jim WILLIAMS, Ding JIANHUA, Junfeng HU, 'Challenges to China's Transition to a Low Carbon Electricity System’ (2011) 39 Energy Policy 4032. 
produced nationally. ${ }^{23}$ Likewise, the average curtailment rate of solar power across China was 10.3 per cent, with a total curtailed amount of 6,620 GWh nationally. ${ }^{24}$ The problem of renewable energy curtailment has not gone unnoticed. Indeed, it has received serious attention from the Chinese central government. In the 2015 US-China Joint Presidential Statement on Climate Change, for example, President Xi Jinping emphasised that 'China will promote green power dispatch, giving priority, in distribution and dispatching, to renewable power generation and fossil fuel power generation with higher efficiency and lower emission levels.' ${ }^{25}$ Similarly, in 2017 Premier Li Keqiang highlighted the urgent need to 'effectively alleviate the problem of wind and solar energy curtailment and to enforce the priority access of electricity from renewable energy to the grid by addressing the institutional and technical challenges.' ${ }^{26}$ Furthermore, as the central powerhouse for energy policy, the National Development and Reform Commission (NDRC) and the NEA have adopted and implemented a range of regulatory mechanisms to ensure access to the network by renewable energy, with the objective of controlling the abandonment of renewable energy in the most heavily-curtailed provinces below certain levels' and ultimately to 'effectively solve the problem of renewable energy curtailment nationwide by 2020.' 27

By reason of the above, this article builds upon existing literature on China's renewable energy law and policy by specifically examining the legal and regulatory framework governing renewable energy generators' priority access to the grid and guaranteed full purchase. In general terms, the discussion addresses key research questions concerning whether China's existing renewable energy law and policy framework provides sufficient support and protection to ensure that renewable energy generators have priority access to the grid, and further,

23 NEA, 'Accessing to the Grid Network by Wind Power in 2016' (2016 年风电并网运行情 况) (2017) <www.nea.gov.cn/2017-01/26/c_136014615.htm>.

24 NEA, 'Press Conference of NEA on Performance of China's Electricity Sector in 2017' (国家能源局新闻发布会介绍 2017 年度相关能源情况等) (2018) <www.nea.gov.cn /2018-01/24/c_136921015.htm>.

25 Ministry of Foreign Affairs of China. 'U.S.-China Joint Presidential Statement on Climate Change' (中美元首气候变化联合声明) (2015) < www.mfa.gov.cn/chn//gxh /zlb/smgg/t1300787.htm>; English version <https://obamawhitehouse.archives.gov/the -press-office/2015/og/25/us-china-joint-presidential-statement-climate-change>.

26 LI Keqiang, 'Report on Government Work' (政府工作报告) (2017) <www.gov.cn/pre mier/2017-03/16/content_5177940.htm>; English version <http://english.www.gov.cn/pre mier/news/2017/03/16/content_281475597911192.htm>.

$27 \quad$ NDRC and NEA, 'Implementation Measures to Resolve the Curtailment of Hydro, Wind and Solar Energy' (解决弃水弃风弃光问题实施方案) (2017) No $1942<\mathrm{http://zfxxgk}$ .nea.gov.cn/auto87/201711/t20171113_3056.htm>. 
what prospects there are for improvement in the long term. The adequacy of existing support and protection is evaluated by consideration of how relevant legal provisions and regulatory measures that aim to ensure renewable energy grid access are stipulated and developed over time. The evaluation also looks at the available remedies for renewable energy generators in the event of curtailment. More specifically, Section 2 of this article commences the discussion with a brief overview of China's power system. The renewable energy policy and legal framework and the issue of curtailment in the renewable energy electricity generation sector are also summarised. How access to the grid and guaranteed full purchase in China is defined under the relevant policy and legal framework, and what regulatory mechanisms have been adopted to deal with this issue, are considered next in Section 3. In order to understand whether the existing regime provides sufficient protection to renewable energy investors and protect their rights of priority access and guaranteed full purchase in China, Section 4 provides insights into the availability of remedies and the judicial and regulatory practices in relation to curtailment disputes. As a survey of relevant cases in China's three leading databases holding Chinese legal cases shows, no cases relating to grid access initiated by the renewable energy generators have ever successfully entered the courtroom. ${ }^{28}$ In light of these discussions, Section 5 then examines the barriers existing under the current system that thwart the uptake of China's renewable energy consumption. Concluding remarks are set out in Section 6.

\section{$2 \quad$ China's Renewable Energy Policies and Laws and Renewable Energy Generation Curtailment}

China has been the world's leading developer of renewable energy in the past decade. ${ }^{29}$ By the end of 2017, China's installed capacity for renewable energy

28 The three databases holding Chinese law cases include: PKU law database (pkulaw.cn), Wusong case search (itslaw.com), and China Judgements Online (wenshu.court.gov.cn). These are three leading databases holding Chinese legal cases in Mainland China. PKU law database and Wusong case search are developed by private companies while China Judgements Online is an official judgment database operated by the Supreme People's Court of the People's Republic of China.

29 IREna (n 14). See also discussion eg, Libin ZHANG, 'China' in Renewable Energy Law Review (Karen B WONG ed, Law Business Research Ltd, London, 2018) Ch 5; Frankfurt School-unep Centre/Bnef, 'Global Trends in Renewable Energy Investment' (Frankfurt School-UnEP Centre, 2013) <www.fs-unep-centre.org $>$. 
power generation reached 650 million kilowatts $(\mathrm{kWs})$, with an increase of 14 per cent compared to 2016. ${ }^{30}$ Capacity increase in wind and solar power had a significant increase of 10.5 per cent and 68.7 per cent respectively. ${ }^{31}$ These outcomes improved further in 2018, with China's National Energy Administration advising that by the end of this year, 'China's renewable energy installation capacity had reached $728 \mathrm{GW}$, an increase of 12 per cent from a year earlier'. ${ }^{32}$

China added 44.26 gigawatts (GW) of solar PV in 2018-this increased total installed capacity by $34 \%$ compared to 2017 and accounted for $53 \%$ of the global market for the technology. Wind power increased by $20.59 \mathrm{GW}$ and total installed capacity reached $184 \mathrm{GW}$ at the end of 2018 . This means that wind and solar accounted for $52.9 \%$ of capacity additions in China, demonstrating their position as a mainstream source of electricity. ${ }^{33}$

Underpinning these advancements in the renewable energy sector is a complex framework of laws and policies, at the core of which is China's REL 2005/2009. Before turning to the discussion on priority access and full purchase, it is helpful to recall the purpose of this law, which is set out in article 1 in the following terms:

This Law is enacted for the purpose of promoting the development and utilization of renewable energy, increasing the supply of energy, improving the structure of energy, safeguarding the safety of energy, protecting environment and realizing sustainable economic and social development.

Article 2 of the law defines 'renewable energy' as 'non-fossil energies, such as wind energy, solar energy, hydroenergy, bioenergy, geothermal energy and ocean energy, etc.' In meeting the stated purposes, the REL 2005/2009 sets out several mechanisms to achieve these ends, namely:

30 NEA (n 24). See also recent discussion on the transformation of China's power system, IEA, China Power System Transformation (n 14).

31 NEA (n 24).

32 Yuanyuan LIU, 'China's renewable energy installed capacity grew 12 per cent across all sources in 2018' (Renewable Energy World, March 6, 2019) < www.renewableenergyworld .com/articles/2019/03/chinas-renewable-energy-installed-capacity-grew-12-percent -across-all-sources-in-2018.html>.

IEA (n 14) 7 . 
(i) A national renewable energy target; 34

(ii) National and local planning systems to facilitate the development and utilization of renewable energy; ${ }^{35}$

(iii) A mandatory grid connection for approved renewable energy generators and prioritised grid access for electricity generated with renewable energy resources; 36

(iv) An obligation on grid enterprises to purchase in full amount the electricity generated by renewable energy resources; ${ }^{37}$

(v) A national feed-in tariff (FiT) system;38 and

(vi) A cost-sharing mechanism supported by central government funds and surcharges collected from electricity sales to finance feed-in tariffs, grid connection, and other key areas of renewable energy development identified by the REL 2005/2009. ${ }^{39}$

Among these supporting mechanisms, the FiT regulation is designed to accelerate investment in renewable energy generation in China. ${ }^{40}$ The FiT provides remuneration to the investors by guaranteeing a price that grid enterprises will pay to energy generators for each kWh of electricity generated from renewable sources. ${ }^{41}$ Typically FiTs are set by regulators based on the cost of generation of each technology, such as wind and solar, and they are often above the retail or wholesale rates of electricity. ${ }^{42}$ In theory, the FiT provides some long-term security to renewable energy generators by guaranteeing their investment return and therefore plays a fundamental role in driving a steady increase in renewable energy generation capacity. ${ }^{43}$ In practice, however, implementing the FiT provision is largely dependent on the precondition that renewable

\footnotetext{
34 REL 2005/2009 (n 6) art 7.

$35 \quad$ REL 2005/2009 (n 6) art 8.

$36 \quad$ REL 2005/2009 (n 6) art 14.

37 REL 2005/2009 (n 6) art 14.

$38 \quad$ REL 2005/2009 (n 6) art 19.

39 REL 2005/2009 (n 6) art 24.

40 Zhen-Yu ZHAO, Jian ZUO, Lei-Lei FAN, and George ZILLANTE, 'Impacts of Renewable Energy Regulations on the Structure of Power Generation in China-A Critical Analysis' (2011) 36 Renewable Energy 24; Judith A CHERNI and Joanna KENTISH, 'Renewable Energy Policy and Electricity Market Reforms in China' (2007) 35 Energy Policy 3616.

41 Jianfei SHEN and Chen LUO, 'Overall Review of Renewable Energy Subsidy Policies in China-Contradictions of Intentions and Effects' (2015) 41 Renewable and Sustainable Energy Reviews 1478.

$42 \quad \mathrm{ZHAO}$ et al (n 40).

43 Hui-ru ZHAO, Sen GUO and Li-wen FU, 'Review on the Costs and Benefits of Renewable Energy Power Subsidy in China' (2014) 37 Renewable and Sustainable Energy Reviews 538.
} 
energy generators have access to the grid network. ${ }^{44}$ As mentioned above, grid access and dispatch are key features of the power system. Sometimes however, renewable energy supply from particular generators is curtailed. There are various reasons for curtailment, including transmission and congestion constraints, operational and system-balancing challenges, as well as technology, safety and grid-access management issues. ${ }^{45}$ Interestingly, in China, and many other countries, as penetration of renewable energy on the grid has grown, levels of curtailment have also tended to rise. ${ }^{46}$ Not surprisingly, as noted above, given the importance of renewable energy generation and supply grid access, such matters are often safeguarded by polices and laws in many countries, including China. ${ }^{47}$

Article 14 of China's REL 2005/2009, discussed in more detail in Section 3 below, requires that renewable energy generators are to be given mandatory access to the grid, and further, that electricity generated from renewable energy is to be fully purchased by the grid enterprises. ${ }^{48}$ Nonetheless, fulfilling mandatory access to the network and full purchase policy of renewable energy have not been entirely successful. ${ }^{49}$ As reported by China's National Energy Administration (NEA), the curtailment of wind power (meaning that electricity was generated but not dispatched) nationwide in 2016 reached 49,700 GWh, accounting for 17.2 per cent of the total wind power produced nationwide. ${ }^{50}$ Provinces with extraordinarily high curtailment rates are mostly located within the areas that are abundant in wind resources, which include: Gansu (43 per cent, 10,400GWh), Xinjiang Autonomous Region (38 per cent, 13,700 GWh), Jilin (30 per cent, 2,90o GWh), Inner Mongolia Autonomous Region (21 per cent, 12,400 GWh). ${ }^{51}$ Similarly, the curtailment of solar power in 2016 was also rather substantial. The average curtailment rate of solar power

44 Laura KANE and Graham AULT, 'A Review and Analysis of Renewable Energy Curtailment Schemes and Principles of Access: Transitioning towards Business As Usual' (2014) 72 Energy Policy 67.

45 Ibid. See also Guo-liang LUO, Yan-ling LI, Wen-jun TANG, Xiao WEI, 'Wind curtailment of China's wind power operation: Evolution, causes and solutions' (2016) 53 Renewable and Sustainable Energy Reviews 1190.

46 Lori BIRD et al, 'Wind and Solar Energy Curtailment: A Review of International Experience' (2016) 65 Renewable and Sustainable Energy Reviews 577.

47 WANG (n 20). For recent discussion and data see eg, IRENA (n 29); IEA/IrENA Global Renewable Energy Policies and Measures Database <www.iea.org/policiesand measures/renewableenergy/>.

$48 \quad$ REL 2005/2009 (n 6) art 14.

49 Canbing LI et al (n 22); KAHRL et al (n 22).

$50 \quad$ NEA (n 23).

51 Ibid. 
across China was 10.3 per cent, with a total curtailed amount of 6,620 GWh nationwide. ${ }^{52}$ Gansu Province and Xinjiang Autonomous Region had the highest curtailment rates in the country, with 30.45 per cent and 32.23 per cent respectively. ${ }^{53}$ Admittedly, there has been some improvement observed with reductions in 2018, with wind and solar generation curtailment falling by 5 and 2.8 percentage points respectively. ${ }^{54}$ Even so, creating adequate incentives at the regulatory, policy and institutional levels to support priority access remains a challenge. Curtailment is one such challenge. Indeed, with regard to the transformative power system changes required to increase the consumption of renewable energy in China, the issues of grid access, including the creation and implementation of the renewable energy legal and policy framework, is ever-present. As existing commentaries have explained, there are technological, economic, political, as well as legal reasons behind the curtailment phenomenon in China. ${ }^{55}$ Additionally, priority access by renewable energy generators is framed as a complex issue for which a range of changes in the development of regulatory and policy framework is required.$^{56}$ The scholarly attention so far on this issue has been mostly on curtailment in general, ${ }^{57}$ or abandonment of renewable energy that is sector-based. ${ }^{58}$ As such, there is a dearth of studies that focus directly on the legal and policy aspects of grid access in China's renewable energy sector. These matters are addressed further in the following discussion.

China's Renewable Energy Law and Policy Framework: Priority Grid Access and Full Purchase Guarantee

Access to the grid and the full purchase guarantee are primarily defined by article 14 of China's REL 2005/2009. That article contains four paragraphs that

52 NEA (n 24).

53 NEA, 'Report on Accessing to the Grid Network by Renewable Energy in the Northwestern Regions in 2016’ (2016 年西北区域新能源并网运行情况通报) (2017). Available online in Chinese at: <www.nea.gov.cn/2017-01/19/c_135996630.htm>.

54 IEA (n 14) 7.

55 SCHUMAN and LIN (n 5); WANG (n 20); QI et al (n 18); LI et al (n 22). The technological, economic and political reasons are discussed briefly across the article. For example, the main reason for curtailment in the wind sector was due to the lack of the use of Low Voltage Ride Through Technology in wind turbines. The economic and political reasons are also part of the analysis in Section 5 of this article.

56 Ibid.

57 QI et al ( $\mathrm{n}$ 18); LI et al (n 22).

$5^{8} \quad$ LUO et al (n 45$)$. 
stipulate the access to the network by renewable energy generators from the perspectives of full purchase, duties of the relevant authority and responsibilities of grid enterprises and renewable energy generators to enforce the full purchase provision while safeguarding grid security. Key features of article 14 are discussed in the following parts. Before turning to that discussion, it is worth pointing out that article 14 is primarily an overarching guideline and lacks detailed provisions on implementation. Accordingly, several supporting regulations and policies have been devised and tested by the government authorities in charge of administering the implementation of the REL 2005/2009. Key examples of these instruments are set out in the Table at the end of this article. This shows that China's renewable energy regulatory framework on grid access is a constellation of relevant policies, laws and regulation, which together aim to define and implement priority access.

\subsection{The Renewable Energy Law 2005/2009: Article 14}

\subsubsection{Prioritised Access and Full Purchase}

At the outset, Article 14 expressly recognises the important role of the State in ensuring that China's renewable energy policy is to be implemented, in part, through the imposition of a 'system of guaranteeing the purchasing of electricity generated by using renewable energy resources in full amount.59 As explained in the second and third paragraphs of Article 14, set out below, the system actually consists of two components: (i) priority grid access; and (ii) a full purchase guarantee. With respect to priority access, Article 14 makes it clear that, subject to special measures, grid enterprises are obliged to give priority to renewable energy by scheduling the generation of electricity with renewable energy resources first. ${ }^{60}$ Grid companies have further obligations, being required to purchase in 'full amount the on-grid electricity of the gridconnected power generation projects.' ${ }^{61}$ As interpreted by some scholars, the full purchase guarantee has two components: (i) mandatory, physical connection of the renewable energy generators to the grid; and (ii) guaranteed full access of electricity to the grid from renewable energy sources. ${ }^{62}$ In light of the fact that physical connection is a precondition of access to the grid, the full purchase requirement entails both components as integral parts to ensure enforceability of this provision.

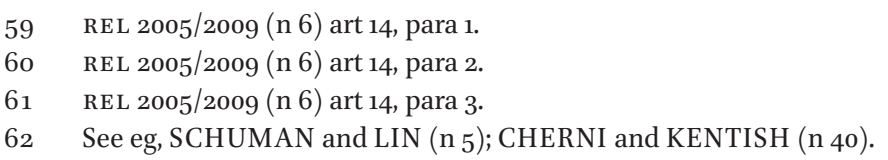




\subsubsection{Duties of Relevant Authorities}

The duties of relevant authorities to design and oversee relevant special measures relating to priority access and the full purchase guarantee are set out in article 14(2), which states:

The energy department of the State Council shall, together with the State Electricity Regulatory Commission and the public finance department of the State Council, and according to the national plan for the development and utilization of renewable energy resources, determine the target proportion, which shall be realized in the planning period, between the electricity generated by using regenerable energy resources and the total electricity generated, and work out the specific measures for power grid enterprises to firstly schedule the generation of electricity with renewable energy resources and purchase electricity generated by using renewable energy resources in full amount. The energy department of the State Council and the State Electricity Regulatory Commission shall urge the implementation of such measures in the planning years.

According to this provision, a two-step process is to be observed. First, relevant authorities that administer the electricity sector are required to identify the expected contribution of renewable energy generated electricity to the total amount of electricity generated nationally, in a given period (the 'target proportion'). Secondly, relevant authorities are required to develop specific measures to ensure that the targeted amount of electricity generated from renewable energies is given priority grid access and purchased in full by grid enterprises. Furthermore, in addition to being responsible for designing the 'specific implementation measures' in respect of 'priority grid-access and guaranteed full purchase', the relevant energy authorities are required to 'oversee the process of implementation of these measures'. ${ }^{63}$

Responsibilities of Grid Companies and Renewable Energy Generators

The REL 2005/2009 also defines the responsibilities of grid enterprises and renewable energy generators in article 14(3) and 14(4), which are expressed as follows:

Power grid enterprises shall conclude grid connection agreements with enterprises which generate electricity by using renewable energy resources and which have gone through the administrative licensing or

63 REL 2005/2009 (n 6) art 14(2). 
archive-filing formalities according to the plan for the development and utilization of renewable energy resources, purchasing in full amount the on-grid electricity of the grid-connected power generation projects which meet the grid connection technical standards in the coverage area of their power grids. Electricity-generating enterprises are obliged to cooperate with power grid enterprises in protecting grid security.

Power grid enterprises shall strengthen the power grid construction, expand the scope of areas where electricity generated by using renewable energy resources is provided, develop and apply intelligent power grid and energy storage technologies, improve the operation and management of power grids, improve the ability for absorbing electricity generated by using renewable energy resources, and provide services for bringing electricity generated by using renewable energy resources onto the grid.

To fulfil the full purchase requirements of this provision, grid enterprises are assigned two major tasks. The first task is to 'expand transmission network coverage and employ new technology so as to increase the capacity of bringing more electricity from renewables onto the grid'. ${ }^{4}$ The second task involves a 'legal obligation' for grid enterprises that requires them to conclude power purchase agreements with renewable energy generators to allow electricity from renewable sources to access the network in full amount. ${ }^{65}$ As compared to the original version of REL of 2005, the amendment of 2009 has incorporated technical standards that renewable energy generators need to satisfy in order to have full access. The 2009 amendment also includes the grid security requirement, which operates as an exception to the priority access and full purchase requirements. In the event that grid security concerns prevail, renewable energy generators 'are obliged to cooperate with power grid enterprises in protecting grid security' ${ }^{66}$

\subsection{Renewable Energy Policy and Law: Supplementary Regulatory Mechanisms}

Shortly after the REL 2005/2009 first took effect in 2006, the NDRC, the NEA and the former State Electricity Regulatory Commission (SERC) $)^{67}$ issued a series of

$64 \quad$ REL 2005/2009 (n 6) art 14(4).

65 REL 2005/2009 (n 6) art 14(3).

66 REL 2005/2009 (n 6) art 14(3).

67 The SERC was dissolved in 2013 and part of its administrative functions are now incorporated into the National Energy Administration. In the areas of renewable energy, the NEA has a Department of Clean Energy and Renewable Energy that harnesses the administrative functions and law and policy enforcing authority of the former SERC. It is worth noting that although the SERC was dissolved, the regulatory documents issued and 
regulatory documents relating to specific provisions adopted by the Law, and also to clarify how relevant clauses are to be implemented in practice. These are listed in the Table at the end of this article. As essential instruments that underpin the implementation of the REL 2005/2009, these regulatory documents have established several mechanisms governing the grid access regime for renewable energy in China. As discussed below, the implementation of these regulatory mechanisms has encountered some difficulties. Nonetheless, overall, they do contribute to an evolving regulatory landscape that aims to achieve the renewable energy objectives of priority access and full purchase. From the dispatch point of view, the Regulation on Power Grid Dispatch which was promulgated in the early 1990s has set the basic tone for access to the network by electricity generators. ${ }^{68}$ Historically, the operating hours of the coal-fired generators (in a given class), which account for the majority of China's electricity generation capacity, were allocated on an equal basis. ${ }^{69}$ This approach was based on ensuring fairness among investors with coal-fired generating assets, encouraging them to produce enough electricity and receive reasonable investment returns. Provincial development and reform commissions have the administrative power to set annual operating hours for generators, subject to the approval by the NDRC. ${ }^{70}$ This particular Chinese 'equal dispatch' feature distinguishes China's power system from most other countries, where grid operators in the latter dispatch generators based on their marginal cost of a given fuel type, eg, coal or gas. ${ }^{71}$ For renewable energy, the question remains whether the new regulatory regime has fundamentally changed the way access to the network is managed in China. The following section examines the regulatory mechanisms that have been established under the mantle of the REL 2005/2009 framework.

promulgated by the SERC that are relevant to the renewable energy sector in China are still valid. Chung-min TSAI, 'Regulating China's Power Sector: Creating an Independent Regulator without Autonomy' (2014) 218 The China Quarterly 452.

68 Ministry of Electric Power Industry of China (dissolved), 'Regulation on Power Grid Dispatch' (电网调度管理条例) (1993) No 3 <http://www.gov.cn/gongbao/content/2011 /content_1860843.htm>.

69 Ibid.

70 Ibid.

71 For more detailed information regarding electricity dispatch and its development in China, see Mun HO, Zhongmin WANG, Zichao YU, 'China's Power Generation Dispatch' (Resources for the Future 2017) in Chinese <www.rff.org/files/document/file /RFF-Rpt-ChinaElectricity.pdf >; Fredrich KAHRL, James H WILLIAMS and Junfeng HU, 'The Political Economy of Electricity Dispatch Reform in China' (2013) 53 Energy Policy 361 . 


\subsubsection{Full Purchase Measure}

The NDRC reaffirms the stance of Chinese central government to support access to the network by renewable energy. In a regulatory document entitled Regulations on the Management of Renewable Energy Generation that was issued in mid-2006, the NDRC stipulates and specifies the responsibilities of the main stakeholders that are involved in renewable energy generation. ${ }^{72}$ Provincial energy authorities were given the power to manage and integrate electricity generation from renewables into the overall electricity generation planning. ${ }^{73}$ Renewable energy generators have the legal obligation to report, on a yearly basis, the installed capacity, as well as the volume of electricity generated and dispatched to the grid network. ${ }^{74}$ Grid enterprises are also required to fulfil mandatory connection and full purchase of renewable energy requirements, by planning and building supporting grid networks in a timely manner to accommodate the development of renewable energy. ${ }^{75}$ Further, to monitor the amount of renewable energy consumption, grid enterprises are also obliged to measure and collect statistics regarding the renewable energy that has been purchased, as well as fulfilling the reporting obligations to surrender such information to relevant provincial and central regulatory authorities. ${ }^{76}$ However, detailed measures as to how priority access to the grid is to be implemented in practice are lacking in this regulatory document.

To ensure enforceability of the priority grid access and full purchase guarantee obligations set down in Article 14 of the Rel 2005/2009, the SERC issued the Regulatory Measures for Grid Enterprises' Full Purchase of Electricity from Renewable Energy (Full Purchase Measure) in 2007. ${ }^{77}$ This measure further defines the power and responsibility of electricity regulatory authorities in respect of supervising and monitoring grid enterprises' compliance with their full purchase of renewable energy obligations. ${ }^{78}$ In addition to the emphasis on various measures that the grid enterprises need to implement to secure priority access, the Full Purchase Measure also contains provisions in relation

72 NDRC, 'Notice of the NDRC on Issuing the Regulations on the Management of Renewable Energy Generation' (国家发展改革委关于印发《可再生能源发电有关 管理规定》的通知) (2006) No 13, art 4 <http://www.ndrc.gov.cn/zcfb/zcfbtz/200602 /t20060206_58735.html>.

73 Ibid.

74 Ibid art 18.

75 Ibid art 11.

76 Ibid art 13 .

77 SERC, 'Regulatory Measures for Grid Enterprises' Full Purchase of Electricity from Renewable Energy' (电网企业全额收购可再生能源电量监管办法) (2007) No 25 $<$ http://jsb.nea.gov.cn/news/2008-3/2008312165921.htm>.

78 Ibid Ch 2. 
to non-compliance. Article 8 stipulates that electricity-dispatching entities, in daily schedule arrangements and real-time dispatching, "[s]hall not limit the generation output of renewable energy except for a force majeure or under circumstances threatening grid security and stability.' ${ }^{\prime}$ The Full Purchase Measure further clarifies that '[c]ircumstances threatening grid security and stability as mentioned shall be defined by the electricity regulatory authority'. ${ }^{80}$ Nonetheless, the SERC failed to fully clarify the circumstances and conditions that affect grid security and stability, leaving a loophole in the system that allows grid enterprises to have discretion to decide when and where the concern of grid security and stability prevails. To date, the circumstances and conditions affecting grid security and stability are yet to be clarified by the relevant energy authority. The Full Purchase Measure also imposes notification and reporting obligations on grid enterprises. For example, in the event that full purchase of renewable energy could threaten the safety and reliability of the grid, grid enterprises must follow certain rules and procedures. These include notifying the renewable energy generators in a written notice about duration of curtailment, the amount of electricity affected and the reason for curtailment. ${ }^{81}$ Grid enterprises are also required to report to the relevant authority about the details of curtailment and improvement measures. ${ }^{82}$ As an integral part of the measures to ensure compliance by the grid enterprises, the Full Purchase Measure also contains penalty provisions in the event of non-compliance. ${ }^{83}$ Article 20 of the Full Purchase Measure provides that grid enterprises' liability, to compensate renewable energy power generators for economic loss, will be triggered by any of the following acts:

1. Failing to construct, or failing to construct in a timely manner, the gridconnection works in a renewable energy electricity generation project;

2. Refusing or obstructing the conclusion of an electricity purchase and sales contract or a grid-connection dispatching agreement with an enterprise generating renewable energy electricity;

3. Failing to provide, or failing to provide in a timely manner, gridconnection services for renewable energy generation;

4. Failing to give priority to renewable energy electricity during dispatch;

5. Otherwise causing a failure of full purchase of renewable energy electricity generated. ${ }^{84}$

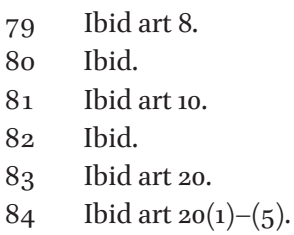


For power-grid enterprises or power dispatching entities involved in any of these acts, which create economic loss for renewable energy power generation enterprises, power-grid enterprises shall be liable for compensation and shall be ordered by electricity regulatory authorities to make corrections within a set time limit. In the case of refusal to make corrections, the electric power regulatory authorities may further impose a fine in an amount not to exceed the original economic loss of the renewable energy power generation enterprise.

\subsubsection{Green Dispatch and Priority Access}

In order to drive some fundamental changes to the electricity dispatching system in China, the NDRC implemented a trial of energy efficiency dispatching, also known as the green dispatching mechanism, which began in $2007 .{ }^{85} \mathrm{With}$ the policy goals of 'increasing power generation efficiency, conserving energy, reducing environmental pollution and advancing structural change for energy and electricity', the green dispatching mechanism aims to establish the dispatching sequences based on the level of energy efficiency of each unit, and the amount of pollutants discharged. ${ }^{86}$ Subject to the requirement that it does not pose threats to stable operation and reliability of the electricity system, green dispatching prioritizes renewable energy to access to the grid, in a dispatching sequence based on the type of unit, which is as follows:

(i) Non-dispatchable renewable energy;

(ii) Dispatchable renewable energy;

(iii) Nuclear;

(iv) Combined heat and power ( $\mathrm{CHP}$ ) generation units where electricity is the by-product;

(v) Natural gas and gasified coal generation units;

(vi) Coal-fired generators; and lastly

(vii) Oil. ${ }^{87}$

The trial program was first initiated in five provinces (including Jiangsu, Henan, Sichuan, Guangdong and Guizhou). However, implementation of the program has faced some significant resistance from provincial authorities in the subsequent rollout to other provinces. ${ }^{88}$

85 NDRC, State Environmental Protection Agency, SERC and Office of National Energy Leading Group (dissolved), 'Workplan for the Pilot Programs on Energy Efficiency Dispatching' (节能发电调度试点工作方案) (2007) No 53 <http://www.gov.cn/zwgk /2007-08/07/content_708486.htm>.

86 Ibid art 1.

87 Ibid art 5 .

88 NEA, 'Supervision Report on the Electricity Dispatching for Energy Efficiency and Emissions Reduction' (华中华东区域节能减排发电调度专项监管报告) (2015) No 12 <http://zfxxgk.nea.gov.cn/autog2/201506/t20150612_1937.htm>. 
Practically, the green dispatching mechanism does not encompass the gap between dispatch sequences and planning for operating hours for generators, the latter of which still largely dominates the real dispatch sequence at the provincial level. To further liberalize the electricity sector, the State Council initiated a reform in 2015 that aims at deregulating certain aspects of China's electricity sector, such as pricing and trading of electricity. As part of the policy package for electricity sector reform in 2015, the State Council issued a regulatory document in order to 'promote reform of the planning system for electricity generation and usage'. ${ }^{89}$ The document, entitled Implementation Opinions on Deregulating the Plans for Electricity Generation and Usage (Implementation Opinions), is a means of ensuring that certain users of electricity, such as agriculture, public utility and residential usage, are protected in the reform process and the full purchase of renewable energy is adequately implemented. ${ }^{90}$ The Implementation Opinions adopt a tiered system to indicate sequence of priority access to the grid by different types of generators. ${ }^{91}$ The top tier priority includes:

(i) Renewable energy generators that are included in the overall national or provincial energy development plan;

(ii) Coal-fired generators that are responsible for peak loading and frequency modulating; and

(iii) CHP units that ensure heating supply and meet the environmental requirements. ${ }^{92}$

Clean energy that is part of the national or local plan for cross-region transmission, such as hydro, nuclear and other generators with ultra-low emissions, are included as a second-tier priority. ${ }^{93}$ Within each tier, provincial authorities are given discretion to decide the sequence of priority, "based on real conditions of the region and in accordance with the principles of ensuring grid safety and taking into account issues such as cost and system flexibility' ${ }^{\prime 4}$ Although renewable energy is placed in the first tier for priority access, the tier system in practice legitimizes priority access by certain coal-fired generators and $\mathrm{CH} P$

\footnotetext{
89 State Council (n 33) Annex 4, 'Implementation Opinions on Deregulating the Plans for Electricity Generation and Usage' (关于有序放开发用电计划的实施意见) <http:// www.ndrc.gov.cn/zcfb/zcfbtz/201511/Wo20151130295800116751.pdf>.

9o Ibid.

$91 \quad$ Ibid part 3(2).

92 Ibid.

93 Ibid.

94 Ibid.
} 
units. ${ }^{95}$ As discussed below, concerns over grid stability in the event of soaring demand, and the need to provide heating in winter months in northern China, often mean that operating hours for renewable energy generators are cut off, leading to the issue of curtailment. ${ }^{96}$

In pursuit of fulfilling the binding target for renewable energy consumption, the NDRC adopted the Management Measures for Full and Guaranteed Purchase of Renewable Energy (Management Measures) in 2016 to further clarify the regulatory arrangements in relation to priority access of renewables in the curtailed provinces. ${ }^{97} \mathrm{In}$ the context of the 2015 reform that allows direct trading of electricity between generators and certain end-users, the Management Measures require grid enterprises in the curtailed provinces to enforce a guaranteed purchase of a certain amount of electricity from renewable energy generators. The guaranteed amount for purchase shall be incorporated in advance into the regional/provincial electricity generation plan, and the contracts between renewable energy generators and grid enterprises on priority access shall be concluded in due course. ${ }^{98}$ Meanwhile, electricity generated outside of the guaranteed amount is treated equally in the electricity trading market for competition. ${ }^{99}$ Priority access is only granted to renewable energy generators if they enter into a contract with buyers in the market. ${ }^{100}$ For the time being, generators operating biomass, geothermal, ocean energy and distributed photovoltaics projects are exempted from participating in market competition, and electricity generated from the said sources are given full and priority access. ${ }^{101}$ The NDRC and the NEA are authorized to determine annually the guaranteed amount of electricity from renewables for priority access in each province based on the capacity of grid system in a given region, as well as the cost and reasonable profit for grid enterprises. ${ }^{102}$ The guaranteed amount is also subject to some annual adjustments if the operational conditions

95 Ibid. Given that coal-fired generators for peak loading and frequency modulating and CH P units for heating purposes are both within the top tier for priority dispatch, the sequence of dispatching electricity from renewable energy, certain coal-fired plants and cH P units are blurred.

96 See section 4.2.2 below.

97 NDRC, 'Management Measures for Full and Guaranteed Purchase of Renewable Energy' (可再生能源发电全额保障性收购管理办法) (2016) No 625 <http://www.nea.gov.cn /135230445_14591534425931n.pdf>.

98 Ibid art 5 .

99 Ibid.

100 Ibid.

101 Ibid art 8.

102 Ibid art 6. 
change. ${ }^{103}$ To ensure implementation of the guaranteed purchase of renewables, the NDRC and the NEA further stipulate that provinces that fail to meet the minimum amount for priority access are banned from constructing new wind or solar projects, including those that have been included in national or provincial planning, or have been granted permits for construction. ${ }^{104}$ For provinces that are not subject to the minimum guaranteed purchase, the NEA further requires that the curtailment rate for wind and solar power generation shall be maintained at less than 5 per cent. ${ }^{105}$ The said penalty provision will also apply to provinces that do not meet this requirement. ${ }^{106}$ The NEA also takes into consideration the technical difficulty that some provinces face in enforcing the minimum guaranteed purchase. Provinces that temporarily fail to achieve the targets due to technical difficulties in the grid system are required to meet the minimum requirement no later than $2020 .{ }^{107}$

\subsubsection{Renewable Electricity Quotas}

The regulatory mechanisms adopted by the NDRC and the NEA, as discussed above, have provided some quick and temporary solutions to the curtailment problem. These mechanisms mainly target grid enterprises to adopt technological and operational management measures to continuously improve system regulation capabilities and to optimize priority access for renewable energy. According to the NEA assessment on the performance of China's electricity sector in early 2018, the issue of renewable energy curtailment has been significantly improved. The average curtailment rates of wind and solar power nationwide have reduced by 5.2 per cent and 4.3 per cent, respectively. ${ }^{108}$ Provinces with extraordinary high curtailment rates such as Gansu and Xinjiang have also seen great improvement in both the wind and solar power sectors. ${ }^{109}$ In the meantime, the NEA has also explicitly pointed out that the improvement happens quickly because some of the existing regulatory mea-

\footnotetext{
103 Ibid.

104 NDRC and NEA, 'Notice of NDRC and NEA on Fully Implementing the Guaranteed Purchase of Electricity from Wind and Solar Generation' (国家发展改革委 国家能 源局关于做好风电、光伏发电全额保障性收购管理工作的通知) (2016) No 1150 <http://www.ndrc.gov.cn/gzdt/201605/t20160531_806133.html>.

105 NEA, 'Notice of the NEA on Matters related to Reducing the Burden on Enterprises in the Field of Renewable Energy' (国家能源局关于减轻可再生能源领域企业负担 有关事项的通知) (2018) No 34 <http://zfxxgk.nea.gov.cn/auto87/201804/t20180426 $-3156 . h \mathrm{htm}>$.

106 Ibid.

107 Ibid.

108 NEA (n 24).

109 Ibid.
} 
sures are 'relatively effective and easy to implement'.110 Although the law and policy imperatives to prioritize renewable energy are intended to give rise to more efficient and greener dispatching, the operation of dispatching across the provinces has yet to be fundamentally changed through the reform process. As the NEA observed in its supervision report that evaluates the trials of green dispatching, the common challenge faced by the provinces is that the adjustment of benefits caused by the policy change among generators has not been effectively managed by provincial energy authorities. ${ }^{111}$ As discussed below, coal-fired generators with strong vested interests to recover their fixed costs lack the incentives to minimize their output as a whole. Realizing the fact that the regulatory mechanisms so far have failed to address the issue of incentives, the NDRC and the NEA highlighted, in the Implementation Measures to Resolve the Curtailment of Hydro, Wind and Solar Energy (Implementation Measures), that a renewable electricity quota system shall be implemented. ${ }^{112}$ Together with the new mechanism proposed, the Implementation Measures also highlight the importance of ensuring priority access by renewable energy, strengthening the monitoring system for renewable energy generation and consumption, deregulating electricity generation plans, and encouraging renewable generators to participate in market trading of electricity. ${ }^{113}$

In March 2018, the NEA issued a Draft Measure for Renewable Electricity Quota and Assessment, an obligatory policy that assigns provincial quotas for hydro and non-hydro renewable electricity consumption. ${ }^{114}$ The renewable electricity quota system mandates priority access of renewable energy to the grid through binding targets and trading of renewable energy certificates (RECS). ${ }^{115}$ The RECS are issued to renewable energy generators for each megawatt-hour that they generate and there are separate obligations for hydropower and other renewable energy (such as wind, solar and biomass). ${ }^{116}$ The new system mandates the selected participants in China's electricity market, including grid enterprises, electricity retail companies, and large end-users taking part in direct trading of power, purchasing a certain amount of RECS

\footnotetext{
110 Ibid.

111 NEA (n 88).

112 NDRC and NEA (n 27).

113 Ibid.

114 NEA, 'Draft Measure for Renewable Electricity Quota and Assessment (draft for comment)' (可再生能源电力配额及考核办法(征求意见稿)) (2018) No 28, art 2 <http:// zfxxgk.nea.gov.cn/auto87/201803/t20180323_3131.htm>.

115 Ibid.

116 Ibid arts 5 and 16.
} 
to prove that a percentage of their electricity comes from renewable sources. ${ }^{117}$ As demonstrated in the policy's objective, the renewable electricity quota system is intended to 'tackle the institutional constraints that are rooted in the pre-reform era'.118 Institutional constraints are characterized by the decentralized energy governance framework to which Chinese provincial governments and state-owned enterprises (SOEs) are wedded, with strong power and decision making authority to shape the outcome of access to the network by different types of generators. From the implementation point of view, the move to a RECs trading system means putting an end to the green dispatch reform. This suggests that to date, the green dispatch reform has not been successful in achieving its policy objective of prioritizing access of renewable energy to the network.

\section{$4 \quad$ Implementing Law and Policy Imperatives on Priority Access in China: Insights from Judicial and Regulatory Practices}

The extraordinary curtailment of wind and solar in a number of provinces in China is a clear indication of policy failure. At the outset, renewable energy generators are protected by China's law and policy framework for renewable energy which imposes an obligation to the grid network companies to fully purchase renewable energy. As stipulated by the NDRC in the Regulations on the Management of Renewable Energy Generation, renewable energy generators are entitled to compensation if grid enterprises fail to fulfil the obligation. ${ }^{119}$ Furthermore, these generators are able to seek remedies through mediation and civil law procedures. Article 19 of this regulation states:

In cases where any dispute arises between a power grid enterprise and a power generation enterprise in relation to priority access, they may apply for mediation through the NDRC. If both parties refuse to settle the dispute through mediation, the dispute may then be settled through civil litigation. ${ }^{120}$

This section provides some insights from regulatory and judicial practices. For regulatory practices, for example, the public regulator (formerly SERC and currently the NEA) has the authority to impose a penalty on grid enterprises for

\footnotetext{
117 Ibid art 7 .

118 Ibid.

119 NDRC (n 72).

120 Ibid art 19.
} 
non-compliance in the event of curtailment. Despite the expressed protection, up to now, no cases of either SERC or NEA implementing the clause on penalty against grid enterprises have ever been reported. ${ }^{121}$ As for the judicial remedies, there are no legal actions on file that have been initiated by the renewable energy generators to claim damages against the grid enterprises. ${ }^{122}$ This raises questions as to whether renewable energy generators are de facto sufficiently protected under Chinese law and to what extent the public regulators in the energy sector are able to provide remedies to renewable energy generators in the event of curtailment. Answers to these questions are two-sided. On the one hand, development of the law and policy framework related to the renewable energy industry in China is still an evolving process in which public regulators often have to manage competing regulatory goals. This is particularly the case when priority access of renewables to the grid is mandated by law, while grid safety and reliability is also a regulatory concern that is beyond all policy goals. As discussed below, the balance of responsibilities between renewable energy generators and grid enterprises in China often comes at a price of lessening protection of the investors. On the other hand, insufficient protection of the investors is a result of the Chinese legal system itself, in which renewable energy generators face enormous challenges in bringing their cases to court.

\subsection{Judicial Practice}

As reported by the NEA, the majority of the complaints in the renewable energy industry, which have been lodged through various channels and handled by the NEA and its provincial branches, relate to access to the grid. ${ }^{123}$ Two reported cases have been initiated by Friends of Nature (FON) against the provincial grid enterprises in Ningxia and Gansu. ${ }^{124}$ These concerned failure

121 This claim is made after reviewing the available reports from SERC ( $\mathrm{n} 133)$ and NEA ( $\mathrm{n} 53$ and $n$ 88).

122 The cases discussed below were not initiated by renewable energy generators, but brought to the courts by a non-government organization, Friends of Nature.

123 NEA, 'Report for the Settlement of Complaints from 12398 Energy Supervision Hotline in November 2017' (2017 年 11 月 12398 能源监管热线投诉举报处理情况通报) (2017) <www.nea.gov.cn/2017-12/15/c_136828872.htm>; Central China Energy Supervision Bureau, 'Report for the Settlement of Complaints from 12398 Energy Supervision Hotline in 2017 in Central China' (华中能源监管局 2017 年 12398 能源监管热线投诉举报受 理处理情况通报) (2018)<www.nea.gov.cn/2018-02/o1/c_136941967.htm>.

124 Friends of Nature v. State Grid Ningxia Electric Power Co (自然之友诉国网宁夏电力公 司) (2018) and Friends of Nature v State Grid Gansu Electric Power Co (自然之友诉国网 甘肃电力公司) (2017). Friends of Nature filed each case in the Intermediate People's Court in Yinchuan and Lanzhou respectively. However, both cases were refused to be accepted at the first trial. Friends of Nature appealed to the Gansu Higher People's Court and the case has now been reheard by the Gansu Kuang District People's Court after the Gansu Higher People's Court overturned the decision of the Lanzhou Intermediate 
to implement the full purchase provision. ${ }^{125}$ In both cases, the NGO plaintiff sued the grid enterprises in Ningxia and Gansu for refusing to purchase all of the electricity produced from wind and solar generators within its geographic boundary. By highlighting Article 14 of the REL 2005/2009 (mandatory connection and full purchase guarantee, discussed earlier), FON reiterated that grid enterprises are obliged to sign purchase contracts with the renewable electricity generators and purchase their electricity in the full amount. In the case of Friends of Nature $v$ State Grid Ningxia Electric Power Co, FON filed this suit in August 2016 and it was accepted by the Yinchuan Intermediate People's Court in January 2018. The main claims from the plaintiff included:

(i) The defendant shall purchase the electricity generated by wind and solar generators within its coverage in the full amount to cease environmental damage caused by electricity generation from coal-fired plants;

(ii) The defendant shall pay for environmental damages caused by electricity generation through coal instead of wind and solar, which is at least 310 million Rм в according to preliminary calculation (compensating environmental losses); and

(iii) The defendant shall make an apology to the public in national and provincial media. ${ }^{26}$

Notably, FON's claim did not centre on priority access, but rather, on ceasing environmental damage. In order to initiate a civil lawsuit against the grid company, renewable energy generators are required by Chinese civil procedural law to present initial and sufficient evidence in relation to the failure of grid enterprises to fulfil the power purchase contract. In reality, however, because of their monopoly status, grid enterprises often seek to exert their strong

People's Court on 24 January 2019. The trial is still in progress. See further, Xuechen WANG, 'Serious Wind and Solar Curtailment: Environmental NGO v State Grid Gansu Electric Power Co. Will Enter Trial' (“弃风弃光”严重: 环保组织诉国网甘肃将进入 实体审理) 29 January 2019 <https://finance.sina.com.cn/chanjing/gsnews/2019-01-29 /doc-ihrfqzka1982995.shtml?mc_cid=ec197aaga7\&mc_eid=ccfb845b51>.

125 Ibid. For further discussion see eg, Chen ZHOU, Shengyuan SHI and Rongde LI, 'Group Sues State Grid Unit for Refusing to Buy Clean Energy' (CiaxinGlobal, 11 April 2018) $<$ www.caixinglobal.com/2018-04-11/group-sues-state-grid-unit-for-refusing-to-buy-cleanenergy-101233152.html>; 'China NGO sues grid firm for flouting renewable power rules' (Reuters, 12 April 2018) <https://af.reuters.com/article/africaTech/idAFL $3 \mathrm{~N}_{1 R P} \mathrm{RP}_{2} \mathrm{SI}$. For more general discussion on standing issues see eg, Tiantian ZHAI and Yen-Chiang CHANG, 'Standing of Environmental Public-Interest Litigants in China: Evolution, Obstacles and Solutions' (2018) 30(3) Journal of Environmental Law 369.

126 Fanchao DIAO, 'An Environmental NGO Claims 300 Million RMB on Curtailment of Wind and Solar and State Grid Ningxia Electric Power Co: Full Purchase of Renewable Electricity is Hard to Achieve (“弃风弃光” 被环保组织索赔 3 亿, 宁夏电网: 做不 到全额收购) 11 April $2018<$ www.thepaper.cn/newsDetail_forward_2069105>. 
bargaining power on renewable energy generators, effectively forcing them to agree on exceptional circumstances, including curtailment. ${ }^{127}$ Consequently, renewable energy generators are constrained from suing the grid enterprises based on contract default. Instead, they are given a very limited choice, to apply to NEA and its branches at provincial levels for mediation. As a practical matter, renewable energy generators in China have long faced a dilemma: consent to potential curtailment in power purchase agreements with the grid enterprises or rely on the mediation process that is of doubtful capacity to protect their interests. However, due to the lack of transparency in the mediation process, it is questionable whether mediation alone can provide sufficient protection and remedies to renewable energy generators in such circumstances.

\subsection{Regulatory Practice}

Regulatory practices concerning priority grid access in China are characterized by a lack of enforcement of certain provisions, and also a departure of implementation from policy goals. The lack of enforcement of certain provisions is the result of two significant factors: (i) the provision itself may lack detail to guide enforcement; and (ii) public regulators themselves may lack authority and resources to strictly enforce the law and regulatory measures within the provincial boundary. A number of studies point out that neither the former SERC, nor the NEA has been granted adequate authority and resources to be an effective regulator. ${ }^{128}$ China's electricity sector regulation is also characterised by multi-agency actors (central government agencies and provincial government) with different agendas and priorities, leading to a further layer of complexity.129

\subsubsection{Lack of Enforcement}

The reluctance of public regulators to enforce penalty provisions against the grid enterprises, as observed by SCHUMAN and LIN, is due to the concern over grid stability. ${ }^{130}$ As highlighted in the REL 2005/2009 and relevant policies underlying priority access, mandatory connection, and full purchase guarantee, practical implementation of these requirements is subject to the

\footnotetext{
127 KAHRL et al ( $\mathrm{n} 71)$.

128 Hon-Wing NGAN, 'Electricity Regulation and Electricity Market Reforms in China' (2010) 38 Energy Policy 2142; QI et al (n 18); KAHRL et al (n 22).

129 Edward A CUNNINGHAM, 'The state and the firm: China's energy governance in context' (Boston University G g g I Working Paper 1, 2015) <http://ash.harvard.edu/files/chinas -energy-working-paper.pdf>.

130 SCHUMAN and LIN (n 5).
} 
caveat that it does not adversely impact grid system security and reliability. ${ }^{131}$ However, the definition of grid security is yet to be clearly set out in any laws or supplementary regulations. In the event of non-compliance with the full purchase provision, for example because of concerns over possible destabilization of the grid, grid enterprises are often exempted from being held responsible for any undue consequences to renewable energy generators. Admittedly, the 2009 amendment to the REL 2005 sought to rebalance the responsibility between grid enterprises and renewable energy generators so as to improve implementation of the full purchase provision. However, instead of imposing sole responsibility on grid enterprises, the 2009 amendment incorporated a provision that renewable energy generators are obliged to meet certain technical standards before the electricity they produce is to be fully purchased by grid enterprises. ${ }^{132}$ In the wind power sector, for example, the use of low voltage ride-through technology in wind turbines is required to ensure that electricity produced by wind turbines can remain online instead of completely going offline when system voltage drops. ${ }^{133}$ The incorporation of the technical standards in the regulatory framework is meant to rebalance the responsibility between renewable energy generators and grid enterprises, with the overall aim to increase the grid system safety and reliability. However, in practice, the incorporation of technical standards has often been delayed. ${ }^{134}$ As a result, an increasing number of renewable generators have been forced to trip offline, leading to higher curtailment and more complaints from the generators, particularly in the wind power industry. ${ }^{135}$

\subsubsection{Implementation Ineffectiveness}

As to the issue of implementation departing from renewable energy policy goals, regulatory practices in the area of priority access are largely determined by the overall structure of electricity sector governance in China, in which provincial authorities are equipped with resources and power to determine the effectiveness of implementation. Although green dispatch was able to deliver some positive outcomes for energy efficiency improvement and cost savings, ${ }^{136}$ the benefits proved to be rather marginal, in contrast to the adverse effects that the trial programs have caused. The NEA 2015 Report, which provides some

\footnotetext{
131 See earlier discussion in Section 2.

132 REL 2005/2009 (n 6) art 14, para 3.

133 SERC, 'Wind Power Safety Supervision Report' (风电安全监管报告) (2011)<jsb.nea.gov .cn/eWebEditor/webpic/201245191745611.pdf>.

134 Ibid.

135 Ibid.

$136 \quad$ NEA (n 88).
} 
specific examples in this regard, reveals that in the process of formulating and implementing the annual plan of electricity generation, the Hunan provincial government deliberately linked the electricity generation quota with the purchase of local coal. ${ }^{137}$ In addition, the Hubei provincial government interfered with the sequence of green dispatching by prioritizing selected mediumsized coal-fired generation units. ${ }^{138}$ The operating hours of these selected units were, on average, nearly the same as the yearly operating hours of the larger units, despite their level of efficiency. ${ }^{139}$ In the long term, the regulatory mechanisms on green dispatching and deregulation of generation planning may blur the order of dispatching for investment and operations that aim to be more efficient under the newly established incentives. One example would be CHP (combined heat and power) units which are primarily used in North China for central heating in winter. ${ }^{140}$ During winter months, these power plants are in fact given priority in dispatch sequence to meet the heating needs of the general public, which has the consequence of curtailing renewable energy, especially wind power. The fact that CHP plants are required to provide heating, and therefore shall maintain high operating hours, will lead to higher investments in CHP plants, which seriously departs from the policy incentive to invest in greener and more efficient generation units. For instance, many installations in Gansu province switch to CHP in winter months just to secure their quota for generation, with the consequence of leaving very limited room in the network for renewables. ${ }^{141}$ Although in theory the provincial government in Gansu has the authority to stop these changes from happening, it is discouraged from doing so. As discussed below, strong local protectionism and provincial interests constitute one of the barriers to ensure priority access of renewable energy in China. From a regulatory point of view, the extremely limited access to the courts in the event of renewable energy curtailment and the departure of policy implementation from its objectives contribute to the failure of reforms concerning priority access for renewable energy generation. The province of Sichuan, for example, reverted to administrative control

\section{Ibid.}

138 The report does not explain the reason for this, but a sensible explanation is that these medium-sized coal-fired generation units are owned by provincial enterprises and they are given de facto priority in the dispatch sequence. For more detailed information about the stakeholders in China's power sector, including the ownership of generators and their distribution, see China Electricity Council, 'Annual Report of the Development of China's Electrical Power Industry’ (中国电力行业年度发展报告) (China Market Press, 2016).

139 NEA (n 88).

140 KAHRL et al (n 71).

141 QI et al (n 18). 
of operating hours for generators after the trial of green dispatching for four years. ${ }^{142}$

Barriers to Implementing Law and Policy Imperatives on Priority Access in China

In the process of reforming the regulatory framework that seeks to ensure priority access of renewable energy to the grid, the legal and regulatory mechanisms adopted by relevant Chinese authorities are currently unable to fundamentally change the province-based system of electricity operation. The above review of judicial and regulatory practices identified several barriers that hinder the reform process. These include lack of protection given to renewable investors, local protectionism, and vested interests of energy soes. Each of the barriers has its roots in the prevailing Chinese legal and institutional systems. In some ways, these barriers are also intertwined, making change difficult to achieve. For instance, past reforms of the electricity system in China were unable to successfully break down the provincial-based electricity operation, which has consequences and implications for electricity operation. Local protectionism and provincial interests define the boundary and style of electricity operation, making it difficult for the regulatory mechanisms designed at the national level to play positive roles in advancing the renewable energy sector. In the long term, given that China's power sector is intended to undergo the significant, and necessary, transition towards increased consumption of electricity from renewable energy, it is important that barriers such as these are tackled by the regulatory and policy framework. Without such action, further reform efforts in the renewable energy sector will be unable to realise expected beneficial outcomes.

\subsection{Lack of Judicial Remedy to Investors}

The protection of renewable energy investors against fundamental breaches of due process in judicial and administrative proceedings is often understood and interpreted as safeguarding investors' legitimate expectations. ${ }^{143}$ Such expectations are based on the laws, regulations, and government commitments that have been put in place to attract investment in renewable energy projects. ${ }^{144}$

\footnotetext{
142 NEA (n 88).

143 WANG (n 20).

144 See for example, Natalie KOZLOV, 'Contracts for Difference: Risks Faced by Generators under the New Renewables Support Scheme in the UK' (2014) 7 The Journal of World Energy Law \& Business 282.
} 
To date however, the Chinese legal system has been unable to provide sufficient protection to renewable energy investors, particularly in the event of curtailment. Two major factors lead to this phenomenon. First, due to the legal requirements associated with initiating a case in a Chinese court, and the difficulty of obtaining sufficient evidence by the investor plaintiffs to substantiate their claims, renewable energy investors are, in practice, prevented from pursuing legal proceedings to settle curtailment disputes. Relevantly, under the Chinese civil procedure law, Chinese courts have set stringent bars to accepting cases. ${ }^{145}$ To officially accept a case, Chinese courts often require substantial evidence concerning the dispute, including the content of the contract and breach of the contract by one of the parties. ${ }^{146}$ Renewable energy generators in China face enormous difficulties in collecting sufficient evidence. Several reasons can be advanced for this situation. One results from restrictive contractual clauses in the power purchase contract with a grid enterprise, whereby renewable energy generators are compelled to consent to a curtailment clause under exceptional circumstances, such as grid security and reliability. In effect, consenting to curtailment clauses of this kind eliminates the legal responsibility that the grid enterprises would otherwise be required to shoulder. Another hurdle faced by renewable energy generators, as discussed below, results from the lack of information sharing with respect to dispatching plans, including curtailment situations, between relevant stakeholders. This constitutes another barrier preventing a plaintiff, including a renewable energy generator, from collecting sufficient evidence to be able to bring their dispute to court. ${ }^{147}$

\subsection{Local Protectionism}

Given the repeated process of centralization and decentralized efforts to reform the sector in the past decades, local protectionism is a recurring theme in China's energy governance. ${ }^{148}$ In the process of making policy changes to ensure priority access of renewable energy, local protectionism comes into play in a major way. While obviously the law and policy making relating to renewable energy are mostly managed by the central government authorities

\footnotetext{
145 See eg, ZHAI and CHANG (n 125).

146 Supreme People's Court of China, 'Interim Provisions on Accepting the Cases by the People's Court' (最高人民法院关于人民法院立案工作的暂行规定) (1997) No 7 $<$ http://pkulaw.cn/(S(21ctss45i13hjxjvmt44tijw))/fulltext_form.aspx?Db=alftwotitle\&Gid $=\mathrm{a} 7 \mathrm{c} 8 \mathrm{offc} 8 \mathrm{odb} 64 \mathrm{dbbdfb}>$.

147 See part 5.3 on the lack of operational transparency of grid companies.

148 Anatole BOUTE and Hao ZHANG, 'The Role of the Market and Traditional Regulation in Decarbonising China's Energy Supply' (2018) 30 Journal of Environmental Law 261; NGAN (n 128); CUNNINGHAM (n 95).
} 
(NDRC and NEA), implementation of the law and policy framework is largely dependent on provincial governments. The trial of green dispatch in a number of provinces provides specific examples as to how and to what extent the local protectionism can result in a deviation between the law's stated goals and its actual implementation. The green dispatch experiments mandate some fundamental changes in dispatch order, but do not include a policy package concerning how the adjustment of benefits among generators can be mediated and the compensation arrangements thereof. ${ }^{149}$ Priority access of renewable energy to the grid entails a transfer of revenues from coal-fired plants to wind and solar power generation. When the demand for electricity is on the rise, priority access of renewable energy poses little threat to the operation of coal-fired generators, hence their aim towards fixed-cost recovery. When the demand for electricity has very little room to grow, and there is a surplus of electricity supply from coal-fired generation, as is the case in China now, renewable energy generators are inevitably challenged by the coal-fired generators. Moreover, since early 2000, coal-fired generators have closely bundled their investments with provincial governments' interests because of the soaring demand for electricity from China's fast-developing industry. ${ }^{150}$ Thus, in any provincial sequence of dispatching, coal-fired generation within provincial boundaries has long been in a dominant position. ${ }^{151}$ Also, in respect of a given type of fuel, such as coal, green dispatching reallocates revenues from generators with low efficiency (small and medium capacity) to big generators with high efficiency. Large coal-fired plants tend to be owned by the central state-owned enterprises (SOEs), whereas small and medium generators are more likely to be owned by provincial and local governments. ${ }^{152}$ Consequently, the reallocation of revenues resulting from the green dispatching experiment is harmful to the operation of small and medium operators, and thus the economic interests of provincial governments. Resistance and intervention from the provincial governments is a result of local protectionism, given that provincial grid enterprises are in charge of provincial and local dispatching. ${ }^{153}$

Furthermore, resistance and intervention from the provincial governments not only jeopardises the priority access of renewable energy within provincial boundaries; it also weakens incentives to cross-provincial trading

\footnotetext{
149 NEA (n 88).

150 BOUTE and ZHANG (n 148).

151 Angang HU, 'Investigation Report on the Serious Loss of Ertan Hydropower Project' (二滩水电项目严重亏损的报告), in National Reports that Influence Decision Making (影响决策的国情报告) (Angang HU ed, Tsinghua University Press, 2002) 226.

$15^{2}$ KAHRL et al ( $\left.\mathrm{n} 71\right)$.

$153 \mathrm{HU}$ (n 151).
} 
of renewable energy. This is illustrated by the situation in the most heavilycurtailed provinces, such as Gansu and Xinjiang, which have far more electricity generated from renewable energy than is needed to meet their internal demand. ${ }^{154}$ Reducing the curtailment in these two provinces would rely on other provinces to import electricity from them. However, the resistance and intervention derived from local protectionism means that other provincial governments would rather rely on generation within the provincial boundary, often from coal-fired generation, to meet their gaps in demand. In this way. the divided electricity operation systems and lack of inter-provincial dispatching reinforce provincial interests and local protectionism. To overcome these challenges, a policy instrument is required; one that could break down the provincial boundaries of electricity operation and facilitate regional and crossprovince electricity trading, thus enlarging the grid system's capacity to absorb more electricity from renewable sources.

\section{$5 \cdot 3 \quad$ Strong Vested Interest of Energy soes}

Despite the early reform effort to break down vertical integration of the electric power enterprises, Chinese soes in the electricity sector have retained strong bargaining power. On the generation side, overall decentralisation resulting from the early reform efforts has not only diversified the ownership of power generation assets between central and local government, but has also shifted the power distribution between them. ${ }^{155}$ Competition between soes at various levels of government has intensified the decentralized character of China's electricity sector governance. In turn, this has resulted in complexities in the process of law and policy implementation that is aimed at changing the status quo in the energy sector. For example, under China's Electric Power Law, guaranteed investment return and regulated pricing are considered to be the core mechanisms to attract investments in the generation sector. ${ }^{156}$ When China's economy started to take off and electricity supply was prioritized as a political task, these two mechanisms proved to be rather effective in the expansion of China's electricity production, with the majority of investments

\footnotetext{
154 NDRC and NEA (n 27).

155 BOUTE and ZHANG (n 148).

156 Electric Power Law of the People's Republic of China (中华人民共和国电力 法) (Adopted by the Standing Committee of the National People's Congress on 28 December 1995, amended for the first time on 24 April 2015, amended for the second time on 29 December 2018) <search.chinalaw.gov.cn/law/detail?LawID=406489>; English version $<$ https://hk.lexiscn.com/law/law-english-1-3381814-T.html $>$.
} 
flowing to the coal-fired generation. ${ }^{157}$ However, since the promulgation of the Electric Power Law in 1995, these two clauses have remained unchanged. Accordingly, although the most recent electricity sector reform in 2015 has made some incremental changes to cautiously liberalize the regulated pricing, China's soes on the generation side are left with stranded assets in thermal coal power. ${ }^{158}$ In order to secure investment recovery, Chinese soes with coalfired generation assets are closely linked with base loading in the electricity dispatching sequence. ${ }^{159}$ In such circumstances, priority access of renewable energy undoubtedly poses an immediate threat to the financial viability of some coal-fired generators, particularly small and medium-sized units.

On the transmission side, one of the outstanding issues that affects the effectiveness of priority access in China is the lack of transparency in relation to how the grid is operated. As suggested above, in the former SERC's Full Purchase Measures, grid enterprises were required to fulfil certain reporting obligations in the event of curtailment. ${ }^{160}$ However, the NEA supervision report in 2016 explicitly points out that, in general, transparency of dispatching in a number of provinces still leaves much to be desired. ${ }^{161}$ The report states, for example, that a number of provincial dispatchers have failed to maintain daily dispatching records or records concerning generators that suddenly trip offline. ${ }^{162}$ Moreover, information sharing relating to dispatching plans between grid enterprises and generators is explicitly required by the relevant regulations. ${ }^{163}$ Nonetheless, in practice, a number of provincial dispatchers refuse to share information regarding daily dispatching plans with renewable energy generators within their dispatching areas. ${ }^{164}$ In the event of renewable energy curtailment, lack of information sharing and insufficient record

\footnotetext{
157 Hao ZHANG, 'Antinomic Policy-Making under the Fragmented Authoritarianism: Regulating China's Electricity Sector through the Energy-Climate-Environment Dimension' (2019) 128 Energy Policy 162; NGAN (n 128).

158 Lauri MYLLYVIRTA, Xinyi SHEN and Harri LAMMI, 'Consequences of China's Investment Surge in Coal Power Generation in 2015' (2015 年中国煤电逆势投资 的后果) (Greenpeace Report, Beijing 2016) <www.greenpeace.org.cn/wp-content /uploads/2015/11/The-consequences-of-coal-investment-in-china.pdf>.

159 NEA (n 88).

160 SERC (2007) (n 78).

161 NEA, 'Supervision Report on Electricity Dispatching Nationwide and Market Order' (2015 年全国电力调度交易与市场秩序监管报告) (2016) No $10<\mathrm{http} / /$ www.chinapower .com.cn/focus/20160615/32102.html >.

162 Ibid.

163 SERC, 'Information Reporting and Disclosure Measures for Electricity Dispatching Agency' (电力调度机构信息报送与披露办法) (2011) No 65 <http://www.cec.org.cn /yaowenkuaidi/2011-08-08/61263.html>.

164 NEA (n 161).
} 
keeping of dispatching plans further exacerbate the difficulty faced by renewable energy generators, either in mediation or in legal proceedings, to prove the fault of grid enterprises in honouring their obligation to guarantee full purchase. The monopoly status of grid enterprises in China also means that they are, as a matter of course, in advantageous positions when negotiating power purchase agreements with generators. When operating the grid network, Chinese grid enterprises have a strong vested interest in exercising some discretion. Two particular situations best exemplify their exercised level of discretion. The first one is implementation of dispatching. The NEA recently discovered that some provincial dispatchers tend to ignore power purchase agreements, and further, that the difference of base contract completion for conventional coal-fired generators in certain localities was as much as 24 per cent. ${ }^{165}$ The discretion of grid enterprises in the process of dispatching complicates implementation of dispatching sequence, generating uncertainties for renewable energy generators and making it difficult to trace failures or faults. The second situation stems from the enforcement of on-grid tariffs (including FiT). The NEA supervision report suggests that several provincial grid enterprises did not enforce, or in some cases selectively enforced, the on-grid tariffs established by the central government. ${ }^{166}$ Similarly, $\mathrm{HO}$ et al observe that, reportedly, renewable energy generators are pressed to enter into contractual relations with provincial grid enterprises at a sale price lower than the official on-grid tariffs. ${ }^{167}$ The practical implication of this kind of practice is that securing access to the grid comes at the price of sacrificing financial viability of renewable energy generators.

\section{Conclusions}

The solutions to alleviating the problem of curtailment require some fundamental changes to the grid operation and dispatching system in China. From a legal point of view, securing investors' confidence and legitimate expectations relies on the systematic functioning of the legal system, in which the courts play an indispensable role. In China, providing sufficient legal protection to the investors in the renewable energy market and ensuring them accessibility to judicial remedy will have the benefit of rebalancing the distribution of power between the renewable energy operators and grid enterprises. It will

\footnotetext{
165 Ibid.

166 Ibid.

167 HO et al (n 71).
} 
also improve the transparency of grid operation in China. In this regard, in order to remove the barriers of bringing cases to court, the contractual arrangements allowing curtailment need to be limited. In particular, the specifications underlying the exceptional circumstances need to be defined by the energyadministering agency (the NEA) so as to the narrow the scope of discretion held by the grid enterprises. The regulatory failure of green dispatching and the lessons from the experiments suggest that a more practical question facing policy makers in China is whether the regulatory mechanisms currently employed can create sufficient incentives to expand provincial electricity operation to region-based operations, thus reducing the barriers emanating from provincial interests and local protectionism. In theory, by imposing binding targets of renewable energy quotas across provinces to increase consumption of electricity from renewable energy, the RECs trading market will have the effect of transcending provincial boundaries to encourage inter-provincial trading of renewable energy. However, as an essential part of the RECs trading market, the level of renewable energy quotas for each province must be set at a reasonable level. This needs to be sufficiently high to provide incentives for provinces, with high electricity demand, to absorb renewable electricity from heavily-curtailed provinces, such as Gansu and Xinjiang. That being said, it must be recognised that setting up reasonable obligations for each province requires a thorough understanding of the status quo of provincial energy structures, as well as the long-term target of renewable energy consumption. Similar to the design and implementation of environmental targets in China, the process of establishing 'reasonable' obligations and subsequently monitoring of these types of targets is difficult. ${ }^{168}$ For example, the targets proposed for 2018 were criticized for being too moderate to drive further investments into the renewable energy industry. ${ }^{169}$ Furthermore, current RECs trading rules contain no review mechanisms for setting up future targets and using the RECs trading market to accelerate consumption and investment of renewable energy. In the long term, the RECs trading market will benefit from a linear target that increases over time to provide certainty to renewable energy investors, promote greater consumption of electricity generated from renewable energies, and avoid the lock-in of coal-fired generation for years to come.

168 Genia KOSTKA, 'Command without Control: The Case of China's Environmental Target System' (2016) 10 Regulation \& Governance 58.

169 Anders HOVE and Daniel WETZEL, 'China is Planning Provincial Quotas for Clean Energy' (China Dialogue, 2018) < www.chinadialogue.net/blog/10574-China-is-plan ning-provincial-quotas-for-clean-energy-/en>. 
TABLE 1 Law and Regulations Governing Access to the Network by Renewable Energy in China

\begin{tabular}{|c|c|c|c|}
\hline $\begin{array}{l}\text { Year of } \\
\text { promulgation }\end{array}$ & Promulgated by & Laws and regulations & \\
\hline 1993 & $\begin{array}{l}\text { Ministry of Electric } \\
\text { Power Industry (MEPI) } \\
\text { (dissolved) }\end{array}$ & Regulation on Power Grid Dispatch & $\begin{array}{l}\text { 电网调度管理 } \\
\text { 条例 }\end{array}$ \\
\hline 2006 & $\begin{array}{l}\text { Standing Committee of } \\
\text { the National People's } \\
\text { Congress }\end{array}$ & $\begin{array}{l}\text { Renewable Energy Law of the } \\
\text { People's Republic of China }\end{array}$ & $\begin{array}{l}\text { 中华人民共可 } \\
\text { 再生能源法 }\end{array}$ \\
\hline 2006 & NDRC & $\begin{array}{l}\text { Notice of the NDRC on Issuing the } \\
\text { Regulations on the Management of } \\
\text { Renewable Energy Generation }\end{array}$ & $\begin{array}{l}\text { 国家发展改革 } \\
\text { 委关于印发《 } \\
\text { 可再生能源发 } \\
\text { 电有关管理规 } \\
\text { 定》的通知 }\end{array}$ \\
\hline 2007 & $\begin{array}{l}\text { NDRC, State } \\
\text { Environmental } \\
\text { Protection Agency } \\
\text { (dissolved), SERC } \\
\text { (dissolved) and Office } \\
\text { of National Energy } \\
\text { Leading Group } \\
\text { (dissolved) }\end{array}$ & $\begin{array}{l}\text { Workplan for the Pilot Programs on } \\
\text { Energy Efficiency Dispatching }\end{array}$ & $\begin{array}{l}\text { 节能发电调度 } \\
\text { 试点工作方案 }\end{array}$ \\
\hline 2007 & SERC (dissolved) & $\begin{array}{l}\text { Regulatory Measures for Grid } \\
\text { Enterprises' Full Purchase of } \\
\text { Electricity from Renewable Energy }\end{array}$ & $\begin{array}{l}\text { 电网企业全额 } \\
\text { 收购可再生能 } \\
\text { 源电量监管 } \\
\text { 办法 }\end{array}$ \\
\hline 2011 & SERC (dissolved) & $\begin{array}{l}\text { Information Reporting and } \\
\text { Disclosure Measures for Electricity } \\
\text { Dispatching Agency }\end{array}$ & $\begin{array}{l}\text { 电力调度机构 } \\
\text { 信息报送与披 } \\
\text { 露办法 }\end{array}$ \\
\hline 2015 & State Council & $\begin{array}{l}\text { Implementation Opinions on } \\
\text { Deregulating the Plans for Electricity } \\
\text { Generation and Usage, Annex } 4 \\
\text { to Opinions of the State Council } \\
\text { on Further Reforming the Electric } \\
\text { Power System }\end{array}$ & $\begin{array}{l}\text { 关于有序放开 } \\
\text { 发用电计划的 } \\
\text { 实施意见, 中共 } \\
\text { 中央国务院关 } \\
\text { 于进一步深化 } \\
\text { 电力体制改革 } \\
\text { 的若干意见 }\end{array}$ \\
\hline
\end{tabular}


TABLE 1 Law and Regulations Governing Access to the Network by Renewable Energy in China (cont.)

\begin{tabular}{|c|c|c|c|}
\hline $\begin{array}{l}\text { Year of } \\
\text { promulgation }\end{array}$ & Promulgated by & \multicolumn{2}{|l|}{ Laws and regulations } \\
\hline 2016 & NDRC & $\begin{array}{l}\text { Management Measures for Full and } \\
\text { Guaranteed Purchase of Renewable } \\
\text { Energy }\end{array}$ & $\begin{array}{l}\text { 可再生能源发 } \\
\text { 电全额保障性 } \\
\text { 收购管理办法 }\end{array}$ \\
\hline 2016 & NDRC and NEA & $\begin{array}{l}\text { Notice of NDRC and NEA on Fully } \\
\text { Implementing the Guaranteed } \\
\text { Purchase of Electricity from Wind } \\
\text { and Solar Generation }\end{array}$ & $\begin{array}{l}\text { 国家发展改革 } \\
\text { 委 国家能源 } \\
\text { 局关于做好风 } \\
\text { 电、光伏发电 } \\
\text { 全额保障性收 } \\
\text { 购管理工作的 } \\
\text { 通知 }\end{array}$ \\
\hline 2017 & NDRC and NEA & $\begin{array}{l}\text { Implementation Measures to Resolv } \\
\text { the Curtailment of Hydro, Wind and } \\
\text { Solar Energy }\end{array}$ & $\begin{array}{l}\text { e解决弃水弃风 } \\
\text { 弃光问题实施 } \\
\text { 方案 }\end{array}$ \\
\hline 2018 & NEA & $\begin{array}{l}\text { Draft Measure for Renewable } \\
\text { Electricity Quota and Assessment } \\
\text { (draft for comment) }\end{array}$ & $\begin{array}{l}\text { 可再生能源电 } \\
\text { 力配额及考核 } \\
\text { 办法(征求意 } \\
\text { 见稿) }\end{array}$ \\
\hline 2018 & NEA & $\begin{array}{l}\text { Notice of the NEA on Matters } \\
\text { related to Reducing the Burden } \\
\text { on Enterprises in the Field of } \\
\text { Renewable Energy }\end{array}$ & $\begin{array}{l}\text { 国家能源局关 } \\
\text { 于减轻可再生 } \\
\text { 能源领域企业 } \\
\text { 负担有关事项 } \\
\text { 的通知 }\end{array}$ \\
\hline
\end{tabular}

